\title{
Loss of a Priming Effect of Glucose on A and D Cell Secretion in Perfused Pancreases from Alloxan-Diabetic Rats: Role of Insulin and Alloxan
}

\author{
V.Grill and S. Efendić \\ Department of Endocrinology, Karolinska Hospital, Stockholm, Sweden
}

\begin{abstract}
Summary. Under normal conditions, glucose acutely influences pancreatic islet B, A and D cell secretion. In addition, prior exposure to glucose modulates the secretory responsiveness of these cells (priming effect). We have tested whether alloxan diabetes influences priming effects of glucose on A and $\mathrm{D}$ cell secretion. Rat pancreases were perfused $72 \mathrm{~h}$ after alloxan treatment. A 20 min infusion of $27.7 \mathrm{mmol} / 1$ of glucose failed to induce priming effects, i.e. it did not inhibit the glucagon nor amplify the somatostatin response to a subsequent (15 min later) infusion of $8 \mathrm{mmol} / 1$ of arginine. Insulin treatment in vivo for $48 \mathrm{~h}$ restored a priming effect of glucose on glucagon secretion in the perfused pancreas, i.e. exposure to $27.7 \mathrm{mmol} / \mathrm{l}$ of glucose now inhibited subsequent arginine-induced glucagon secretion by $48 \%$ relative to a stimulation period with arginine preceding the glucose pulse (from $5.0 \pm 0.7$ to $2.6 \pm 0.5 \mathrm{ng} / \mathrm{min}, p<0.01$ ). Conversely, insulin treatment in vivo did not restore a priming effect of glucose on soma-
\end{abstract}

tostatin secretion. Other effects noted were failure of $27.7 \mathrm{mmol} / 1$ glucose to stimulate, during its presence, the release of somatostatin from pancreases of the diabetic rats whether untreated or insulin-treated. Furthermore, insulin treatment abolished the arginine-induced somatostatin secretion observed in pancreases from untreated rats. It is concluded that short-term alloxan diabetes leads to loss of a priming effect of glucose on glucagon secretion and that this $a b-$ normality is secondary to direct or indirect effects of insulinopenia. Concomittant abnormalities of glucose regulation of somatostatin secretion may, in part, be secondary to a cytotoxic effect of alloxan on the D cell.

Key words: Insulin secretion, rats, glucagon secretion, somatostatin secretion, alloxan diabetes, glucose regulation of secretion, glucose metabolism
Under normal conditions the prevailing concentration of glucose participates in the regulation of insulin, glucagon and somatostatin secretion $[1,2]$. However, also priming effects of glucose modulate the secretion of these three hormones. Short-term previous exposure to glucose thus profoundly amplifies the insulin response not only to glucose [3-5] but also to subsequent stimulation with other secretagogues [6]. Also the somatostatin response to glucose [7] or arginine [8] is enhanced, albeit moderately, by previous exposure to glucose. As for glucagon secretion, priming with glucose inhibits subsequent arginine-induced glucagon secretion [8-10]. The mechanisms behind the acute and priming effects of glucose seem to be partly different since both require the metabolism of glucose but only the former effect is tightly coupled to alterations in calcium fluxes and cyclic AMP metabolism [5].

Diabetes mellitus is associated with defective regulation by ambient glucose of glucagon [11] as well as somatostatin secretion [2]. To our knowledge investiga- tions on priming effects of glucose on secretory responses in diabetes are lacking. The aims of the present study were (a) to investigate the influence of an insulinopenic diabetic state on priming effects of glucose, and (b) to test whether insulin treatment in vivo would influence priming. To this end the effects of previous administration of glucose on subsequent arginine-induced glucagon and somatostatin secretion were compared in perfused pancreas from untreated or insulin-treated alloxan diabetic rats.

\section{Material and Methods}

\section{Animals}

Male Sprague-Dawley rats were obtained from Anticimex, Stockholm, Sweden. They were fed ad libitum with a commercial pelleted diet. For reasons outlined in the Discussion, only limited investigations (Table 1) were carried out in normal rats. In all others diabetes mellitus was induced in the fed state by injection into a tail-vein of 
Table 1. Characteristics of normal and alloxan-diabetic rats with or without insulin treatment

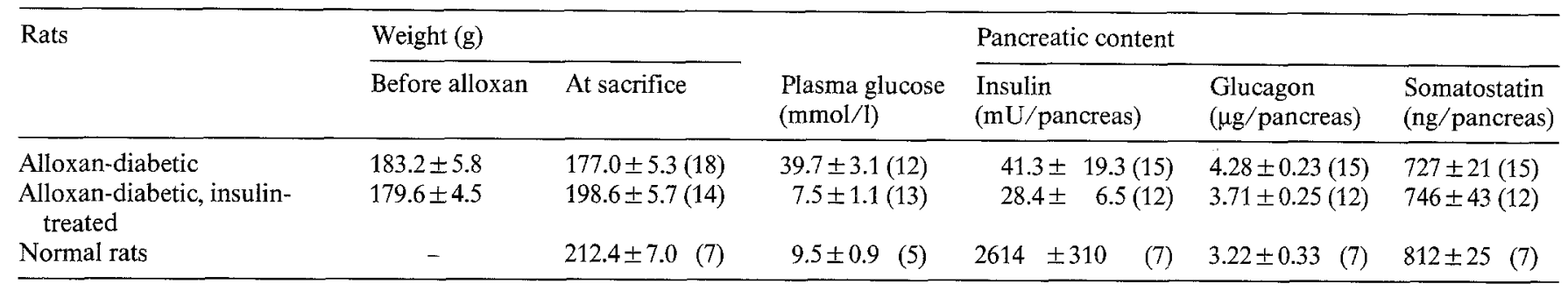

Results expressed as mean \pm SEM, number of observations in parentheses

$60 \mathrm{mg} / \mathrm{kg}$ body weight of alloxan monohydrate (Sigma, St Louis, Missouri, USA). Alloxan was dissolved in ice-cold saline immediately before use to yield a concentration of $20 \mathrm{mg} / \mathrm{ml}$. Injection time was $10 \mathrm{~s}$. The animals were then placed in metabolic cages with free acess to food and water. Diabetes was diagnosed by the appearance of glycosuria $12-24 \mathrm{~h}$ after alloxan. None of the animals developed ketonuria which was tested for in every case. Three days after alloxan, the pancreas was isolated as described below and the animals sacrificed. These diabetic animals were designated the untreated group. Other diabetic animals were started on insulin treatment with SC injections of heat-treated Ultralente insulin on the morning following alloxan administration. They were maintained on $4-8 \mathrm{IU} / 24 \mathrm{~h}$ distributed in two daily injections. Relative to induction of diabetes, the day of sacrifice was identical in both groups.

\section{Perfused Pancreas Preparation}

The animals were anaesthetized by IP injection of $100 \mathrm{mg} / \mathrm{kg}$ body weight of pentobarbital. The pancreas was isolated completely free from adjacent organs according to the technique of Loubatières et al. [12]. After isolation and removal of the pancreas and before sacrifice, a blood sample was obtained through cardiac puncture for the determination of plasma glucose. The pancreas was perfused through the abdominal aorta with a Krebs-Henseleit bicarbonate buffer containing $20 \mathrm{~g} / 1$ of bovine albumin (Sigma, St Louis, Missouri, USA) and when not otherwise indicated $-3.9 \mathrm{mmol} / 1$ of glucose. Flow rates were kept between 2.2 and $2.7 \mathrm{ml} / \mathrm{min}$ and were stable throughout the experiments.

\section{Experimental Protocols}

A preperfusion period of $15 \mathrm{~min}$ (not indicated in figures or tables) was allowed before the start of each experimental protocol; the latter time-point was designated as min zero. Two different protocols were employed. In both, two identical pulses of $8 \mathrm{mmol} / \mathrm{l}$ of arginine were administered between min $0-5$ and 50-55. The test protocol included a pulse of $27.7 \mathrm{mmol} / \mathrm{I}$ of glucose between $\min 15-35$. In the other protocol (control) the glucose concentration was kept at $3.9 \mathrm{mmol} / 1$ throughout the experiment. Samples of perfusate were obtained before all changes in perfusate composition and at $1 \mathrm{~min}$ intervals during arginine infusions. During the glucose infusion min (15-35) a single sample was secured from the pooled perfusate. Samples were collected in prechilled plastic tubes containing $0.1 \mathrm{ml}$ of Trasylol, then frozen and stored at $-20^{\circ} \mathrm{C}$.

\section{Extraction of Pancreatic Hormones}

After the completion of the perfusion protocol, the perfused organ was rapidly frozen. It was kept then at $-70^{\circ} \mathrm{C}$ for $1-6$ months. The extraction procedure consisted of cutting the frozen pancreas in four to five pieces, which were placed in $5 \mathrm{ml}$ of ice-cold acid ethanol ( $75 \mathrm{eth}$ anol: $25 \mathrm{H}_{2} \mathrm{O}$ : 1.5 concentrated $\left.\mathrm{HCl}, \mathrm{v} / \mathrm{v}\right)$. The organ pieces were minced with the aid of a Polytron (Kinematica, Luzern, Switzerland, $20 \mathrm{~s}$, position 7). The resulting mixture was allowed to stand at $4{ }^{\circ} \mathrm{C}$ for $16 \mathrm{~h}$ after which it was diluted with $25 \mathrm{ml} \mathrm{H}_{2} \mathrm{O}$ and centrifuged at $48000 \times g$ for $20 \mathrm{~min}$. The clear infranatant was then secured and assayed in several dilutions $(1 / 10$ to $1 / 10000)$ for contents of insulin, glucagon and somatostatin as described below.

\begin{abstract}
Assays
Plasma glucose was measured by a glucose oxidase method [13]. The presence of glucose or ketones (acetoacetate) in the urine was tested for with reagent sticks from Ames Laboratory, UK. Insulin was assayed radioimmunologically using charcoal addition to separate free and bound antibody [14]. The sensitivity of this assay was $8 \mathrm{mU} / 1$ and the coefficient of variation $\pm 10 \%$. Glucagon was assayed as described [15] using $30 \mathrm{~K}$ antibodies obtained from Dr. Unger, Dallas, Texas. The sensitivity was about $10 \mathrm{pg} / \mathrm{ml}$ and the coefficient of variation \pm $7 \%$. Somatostatin was assayed as described $[16,17]$ using own antibodies (R141E) [17]. The sensitivity was about $2 \mathrm{pg} / \mathrm{ml}$ and the coefficient of variation $\pm 15 \%$.
\end{abstract}

\section{Presentation of Results}

Results are presented as mean \pm SEM. Tests of significance were carried out using Student's t-test for paired or unpaired differences as evident or indicated in text and tables.

\section{Results}

\section{Weights, Plasma Glucose and Contents of Pancreatic Hormones in Untreated and Insulin-Treated Diabetic Rats}

Normal weight gain was halted in the alloxan-injected untreated group, while it was preserved in the insulin treated group (Table 1). Also plasma glucose measurements, obtained before sacrifice, demonstrated a marked difference between the two groups of animals. Hence insulin treatment was effective in influencing important metabolic parameters of the diabetic animals.

As expected the pancreatic insulin content was reduced by $98 \%-99 \%$ in the diabetic animals when compared with pancreases of normal rats (Table 1). This effect of alloxan on the B cell was not modified by insulin treatment. The contents of glucagon and somatostatin were not significantly changed by alloxan diabetes or the insulin treatment thereof and exceeded one hundred-fold or more the amount released during perfusions. 
Table 2. Effects of previous exposure to elevated glucose on arginine-induced insulin, glucagon and somatostatin secretion from untreated or insulintreated alloxan-diabetic rats

\begin{tabular}{|c|c|c|c|c|c|c|c|c|c|c|}
\hline \multirow[t]{2}{*}{ Alloxan diabetic rats } & \multirow{2}{*}{$\begin{array}{l}\text { Number of } \\
\text { experiments }\end{array}$} & \multicolumn{3}{|c|}{ Insulin (mU/5 min) } & \multicolumn{3}{|c|}{ Glucagon (ng/5 min) } & \multicolumn{3}{|c|}{ Somatostatin (pg/5 min) } \\
\hline & & $\begin{array}{l}\text { Arginine } \\
\text { 1st pulse }\end{array}$ & $\begin{array}{l}\text { Arginine } \\
\text { 2nd pulse }\end{array}$ & $p$ & $\begin{array}{l}\text { Arginine } \\
\text { 1st pulse }\end{array}$ & $\begin{array}{l}\text { Arginine } \\
\text { 2nd pulse }\end{array}$ & $p$ & $\begin{array}{l}\text { Arginine } \\
\text { 1st pulse }\end{array}$ & $\begin{array}{l}\text { Arginine } \\
\text { 2nd pulse }\end{array}$ & $p$ \\
\hline \multicolumn{11}{|l|}{ Untreated rats } \\
\hline $\begin{array}{l}\text { Control (glucose } \\
3.9 \mathrm{mmol} / 1, \min 0-55)\end{array}$ & 8 & $0.18 \pm 0.07$ & $0.15 \pm 0.06$ & NS & $7.9 \pm 1.5$ & $6.6 \pm 2.0$ & NS & $86.5 \pm 31.7$ & $50.6 \pm 25.4$ & NS \\
\hline $\begin{array}{l}\text { Priming (glucose } \\
27.7 \mathrm{mmol} / 1, \min 15-35 \text { ) }\end{array}$ & 8 & $0.06 \pm 0.04$ & $0.13 \pm 0.10$ & NS & $6.6 \pm 1.1$ & $5.5 \pm 1.1$ & NS & $70.3 \pm 29.3$ & $55.9 \pm 19.3$ & NS \\
\hline \multicolumn{11}{|l|}{ Insulin-treated rats } \\
\hline $\begin{array}{l}\text { Control (glucose } \\
3.9 \mathrm{mmol} / 1, \min 0-55 \text { ) }\end{array}$ & 5 & $0.13 \pm 0.13$ & $0.11 \pm 0.11$ & NS & $5.0 \pm 1.2$ & $4.4 \pm 0.8$ & NS & $4.6 \pm 21.8$ & $3.9 \pm 19.1$ & NS \\
\hline $\begin{array}{l}\text { Priming (glucose } \\
27.7 \mathrm{mmol} / 1, \min 15-35 \text { ) }\end{array}$ & 9 & $0.04 \pm 0.01$ & $0.07 \pm 0.03$ & NS & $5.0 \pm 0.7$ & $2.6 \pm 0.5$ & $<0.01$ & $23.3 \pm 20.1$ & $-18.3 \pm 19.0$ & NS \\
\hline
\end{tabular}

Results are expressed as mean \pm SEM of the integrated secretion during the presence of arginine from which basal secretion rates (as estimated from the values obtained immediately before each stimulation period) have been subtracted. Secretion was measured in response to two $5 \mathrm{~min}$ pulses of $8 \mathrm{mmol} / 1$ of arginine which were administered $45 \mathrm{~min}$ apart. In priming experiments, we tested the effect of a $20 \mathrm{~min}$ infusion of $27.7 \mathrm{mmol} / 1$ of glucose on the secretory response to the second pulse of arginine. $p$-values indicate significance of difference between first and second pulse responses to arginine (paired differences). NS = not significant
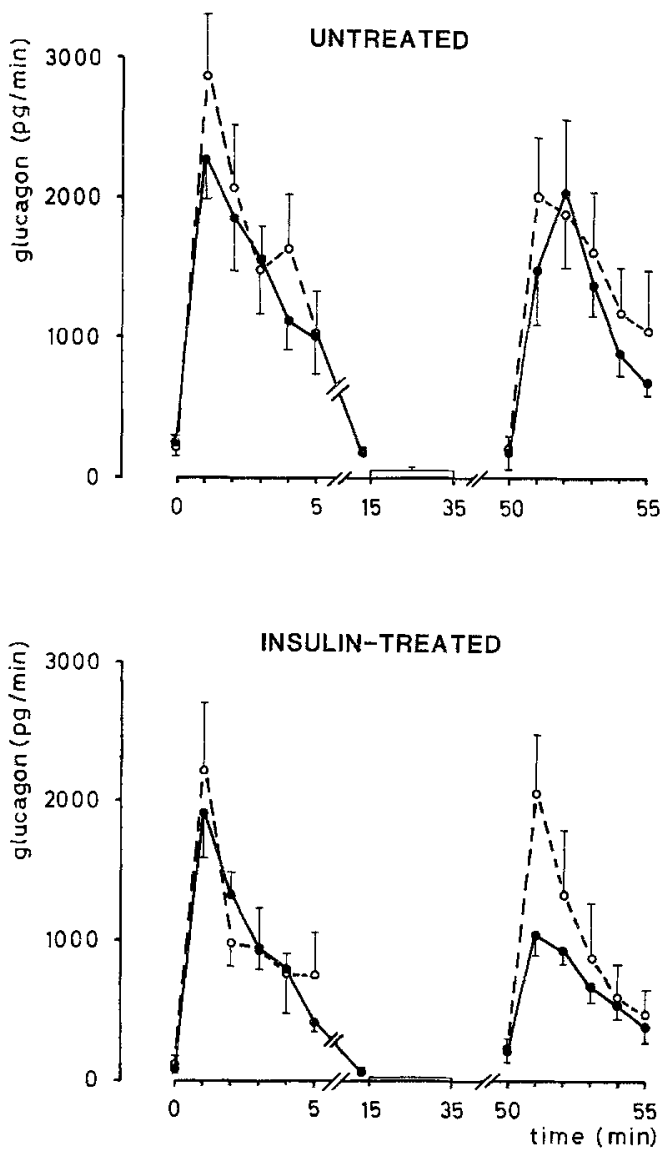

Fig. 1. Glucagon secretion in response to glucose and arginine from perfused pancreases of alloxan-diabetic rats. Five minute pulses of $8 \mathrm{mmol} / \mathrm{l}$ of arginine were administered between min $0-5$ and $50-55$ with (- - ) or without $(\mathrm{O}---\mathrm{O})$ an intervening infusion of $27.7 \mathrm{mmol} / 1$ of glucose. Mean secretory rate during the period of glucose infusion ( $\min 15-35$ ) is indicated by the unfilled boxes. Results expressed as mean $\pm \mathrm{SEM}$; number of experiments indicated in Table 2
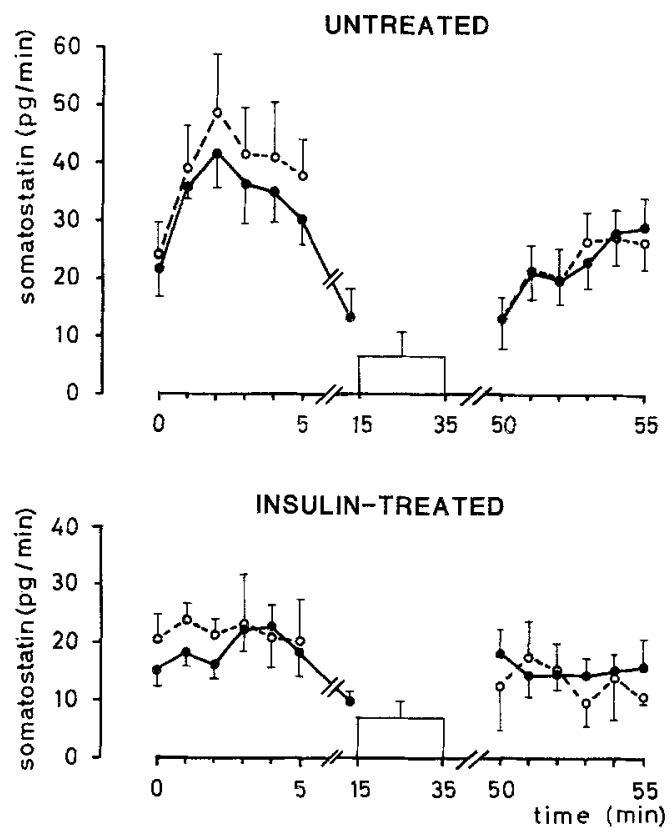

Fig. 2. Somatostatin secretion in response to glucose and arginine from perfused pancreases of alloxan-diabetic rats. Symbols (- with, $\mathrm{O}--\mathrm{O}$ without an intervening infusion of $27.7 \mathrm{mmol} / \mathrm{l}$ of glucose) and experimental conditions as in Figure 1 and in Table 2

\section{Secretory Responses: Insulin}

As expected, insulin secretory responses were insignificant in response to arginine (Table 2) and completely absent in response to glucose (not shown) whether measured from pancreases of untreated or insulintreated animals. 


\section{Glucagon}

In the untreated diabetic rats a 20 min infusion of $27.7 \mathrm{mmol} / 1$ of glucose did not significantly inhibit 'basal' release rates $(174 \pm 67$ prior to infusion versus $50 \pm 20.5 \mathrm{pg} / \mathrm{min}$ during infusion, $p<0.1$ ). No priming effect could be demonstrated on subsequent arginineinduced glucagon secretion (Fig. 1, Table 2).

Insulin treatment in vivo did not significantly alter basal release rates of glucagon from the perfused pancreas, nor arginine-induced release. An infusion of $27.7 \mathrm{mmol} / 1$ of glucose significantly depressed glucagon secretion (from $64 \pm 26$ to $15 \pm 8 \mathrm{pg} / \mathrm{min}$, $p<0.05$ ). Insulin treatment in vivo was effective in restoring a priming effect of glucose on glucagon secretion. Thus, previous exposure to $27.7 \mathrm{mmol} / 1$ of glucose significantly inhibited subsequent arginine-induced glucagon secretion by $48 \%$ compared with a stimulation with arginine without a preceding glucose pulse (from $5.0 \pm$ 0.7 to $2.6 \pm 0.5 \mathrm{ng} / 5 \mathrm{~min}, p<0.01$, Fig. 1 , Table 2 ).

\section{Somatostatin}

During its presence, elevated glucose failed to stimulate somatostastin release from the perfused pancreases of untreated diabetic rats (Fig.2). The pulse of elevated glucose was also without effect on the subsequent secretory response to arginine (Fig. 2, Table 2). Insulin treatment neither restored an acute nor a priming effect of glucose. The only apparent effect of insulin treatment in vivo on somatostatin secretion was to inhibit the moderate arginine-induced response seen in pancreases from untreated rats (from $78.4 \pm 20.9(n=16)$ to $16.6 \pm$ $14.8 \mathrm{pg} / 5 \mathrm{~min}(n=14), p<0.05$, Student's t-test unpaired differences).

\section{Discussion}

The use of B-cytotoxic drugs, such as alloxan and streptozotocin, have provided a convenient and much employed basis for the study of experimental diabetes mellitus. Several studies have however demonstrated the potential noxious effects of such drugs on other cells in the organism [18]. Also the A and D cells can be affected by high concentrations of alloxan and streptozotocin $[19,20]$. In order to distinguish between such effects of alloxan on the one hand and the effect of insulinopenia on islet secretory responses on the other, we have in the present study compared A and D cell secretion in untreated and insulin-treated alloxan-diabetic rats. Such an approach obviously requires insulin treatment to be effective enough to normalize substantially (though, realistically, by no means completely) the manifestations of diabetes. The fact that insulin treatment did lower plasma glucose and did restore weight gain in the diabetic rats would attest to its desired efficacy.

The main finding of the present study is the demonstration of a hitherto unrecognized abnormality of A cell regulation by glucose, i. e. loss of a priming effect. A priming effect has previously been demonstrated in vitro in the rat both in the fasted and fed state [8,9]. A recent study employed protocols identical to the present ones [8]. A priming effect, albeit moderate, on glucagon secretion has also been observed in man [10]. These findings indicate that a priming effect of glucose on glucagon secretion may play a role in the normal homeostasis of nutrients and consequently, that the loss of this glucostatic mechanism could add to the derangements of metabolism seen in diabetes.

Insulin treatment in diabetic states partly or wholly corrects defective (absent or blunted) regulation by ambient glucose of glucagon secretion [11]. Our findings of significant inhibition during glucose infusion only after insulin is thus in line with previous findings [21]. The restoration by insulin of an immediate effect of glucose may, at least in part, be mediated by insulin per se since in vitro high concentrations of exogenous insulin can suppress glucagon secretion from diabetic pancreases [22-24].

Insulinopenia also underlies the loss of a priming effect of glucose on glucagon secretion. However, we do not know whether glucose-induced A cell priming is influenced by insulin directly or indirectly for example by insulin effects on glucose homeostasis. Evidence indicates that in normal rats the metabolism of glucose is essential for induction of priming in A and B cells [9]. It thus seems reasonable to suggest that a direct or indirect role of insulin on A cell priming would be coupled to an effect on metabolic events in the glucagon-producing cells.

Our results on somatostatin release are partly in line with those of other investigators. As in our experiments, elevated glucose failed to stimulate the release of somatostatin in short-term alloxan diabetic dogs in vivo [25], in the perfused pancreas from short-term streptozotocin-diabetic dogs in vitro [26] and in isolated islets from long-term streptozotocin-diabetic rats [27]. These observations have now been extended by our observation of a concomittant loss of a priming effect of glucose. Our results differ from those of Trimble et al. [27] with respect to the effects of insulin treatment since in the latter study insulin in vivo restored a definite stimulatory response to glucose. Although the effects of glucose on somatostatin release are moderate $[8,16]$ we think it unlikely that they were absent in the present study merely because of problems of detection. Instead the fact that our insulin treatment period was restricted to $48 \mathrm{~h}$ before sacrifice compared with 10-21 days [27] could be of importance for the failure of insulin to restore glucose effects in our experiments. However, a cytotoxic effect of alloxan on the D cell must also be considered. It has indeed been demonstrated that pretreatment in vitro of pancreases of normal animals with alloxan severely comprises the secretory potential of the D cell [20]. Furthermore, the glibenclamide-induced somatostatin secretion was reduced in proportion to the dose of allox- 
an when tested in pancreases 3 days after alloxan (Efendic, unpublished observations).

A toxic effect of alloxan on the D cell could possibly explain our unexpected findings that insulin treatment in vivo abolished the moderate somatostatin response to arginine seen in the untreated diabetic animals. Since insulinopenia of the diabetic state may enhance the somatostatin response to different stimuli (excluding glucose) by factors presently unknown [2], we tentatively suggest that, in our experiments, insulin treatment could have unmasked a damage to the D cell secretory machinery induced by alloxan. Further studies will have to be carried out in order to verify this hypothesis.

Acknowledgements. We are indebted to Miss R. Partanen, Mrs. M.Olsson, Mrs. E. Sandberg and Mrs. A. Wendt for expert and dedicated assistance. Excellent secretarial work was performed by Mrs. K. Breitholtz. This work was supported by the Swedish Medical Research Council (grant no. 19X-04540-06A), The Nordic Insulin Foundation, the Swedish Diabetes Association, the Åke Wibergs Foundation and the Magnus Bergvall Foundation.

\section{References}

1. Gerich JE, Charles MA, Grodsky GM (1976) Regulation of pancreatic insulin and glucagon secretion. In: Knobil E, Sonnenschein RR, Edelman IS (eds) Annual Review of Physiology, vol 38. Annual Reviews, Palo Alto, pp 353-388

2. Hermansen K (1980) Secretion of somatostatin from the normal and diabetic pancreas. Studies in vitro. Diabetologia 19:492-505

3. Grodsky GM, Curry D, Landahl H, Bennett LL (1969) Further studies on the dynamic aspects of insulin release in vitro with evidence for a two-compartmental storage system. Acta Diabetol Lat 7 (Suppl 1): 554-579

4. Cerasi E (1975) Potentiation of insulin release by glucose in man. I Quantitative analysis of the enhancement of glucose-induced insulin secretion by pretreatment with glucose in normal subjects. Acta Endocrinol 79: 483-501

5. Grill V, Adamson U, Cerasi E (1978) Immediate and time-dependent effects of glucose on insulin release from rat pancreatic tissue. J Clin Invest 61: 1034-1043

6. Grill V, Rundfeldt M (1979) Effects of priming with glucose on insulin secretion from rat pancreatic islets. Increased responsiveness to other secretagogues. Endocrinology 105:980-987

7. Kanatsuka A, Makino H, Matsushima Y, Osegawa M, Kasanuki J, Miyahira M, Yamamoto M, Kumagai A (1981) Effect of glucose on somatostatin secretion from isolated pancreatic islets of normal and streptozotocin-diabetic rats. Endocrinology 109:652-657

8. Grill V, Rundfeldt M, Efendić S (1981) Previous exposure to glucose enhances somatostatin secretion from the isolated perfused rat pancreas. Diabetologia 20:495-500

9. Grill V, Adamson U, Rundfeldt M., Andersson S, Cerasi E (1979) The glucose memory of pancreatic $\mathrm{B}$ and $\mathrm{A}_{2}$ cells. Evidence for common time dependent actions of glucose on insulin and glucagon secretion. J Clin Invest 64: 700-707

10. Adamson U, Grill V, Efendic S (1981) Previous exposure to glucose enhances insulin and suppresses glucagon responses to arginine in man. Acta Diabetol Lat 18: 173-179

11. Unger RH (1978) Role of glucagon in the pathogenesis of diabetes: the status of the controversy. Metabolism 27: 1691-1709
12. Loubatières A, Mariani MM, Ribes G, de Malbose H (1969) Etude expérimentale d'un nouveau sulfamide hypoglycémiant particuliérement actif, le HB 419 ou glibenclamide. I. Action bêtacytotrope et insulinosécrétrice. Diabetologia $5: 1-10$

13. Hugget AS, Nixon DA (1957) Use of glucose oxidase peroxidase and $o$-dianisidine in determination of blood and urinary glucose. Lancet 2: 368-370

14. Herbert V, Lau KS, Gottlieb CW, Bleicher SJ (1965) Coated charcoal immunoassay of insulin. J Clin Endocrinol 25: 1375-1384

15. Faloona GR, Unger RH (1974) Methods of hormone radioimmunassay. In: Jaffe BM, Behrman HR (eds) Radioimmunoassay technique. Academic Press, London, New York, pp 324-326

16. Efendić S, Nylén A, Roovete A, Uvnäs-Wallensten K (1978) Effects of glucose and arginine on the release of immunoreactive somatostatin from the isolated perfused rat pancreas. FEBS Lett 92: $33-35$

17. Efendić S, Enzmann F, Nylén A, Uvnäs-Wallensten K, Luft R (1979) Effect of glucose/sulfonylurea interaction on release of insulin, glucagon and somatostatin from isolated perfused rat pancreas. Proc Natl Acad Sci USA 76: 5901-5904

18. Rerup CC (1970) Drugs producing diabetes through damage of the insulin secreting cells. In: de V. Cotten M. (ed) Pharmacological Reviews. Vol 22. Williams \& Wilkins, Baltimore, pp 485-518

19. Pagliara AS, Stillings SN, Zawalich WS, Williams AD, Matschinsky FM (1977) Glucose and 3-0-methylglucose protection against alloxan poisoning of pancreatic alpha and beta cells. Diabetes 26 : 973-979

20. Goto X, Berelowitz M, Frohman LA (1976) Acute effects of alloxan and streptozotocin-induced insulin deficiency on somatostatin and glucagon secretion by the perfused isolated rat pancreaticoduodenal preparation. Diabetologia 20:66-71

21. Matschinsky FM, Pagliara AS, Hover BA, Pace CS, Ferendelli JA, Williams A (1976) Hormone secretion and glucose metabolism in islets of Langerhans of the isolated perfused pancreas from normal and streptozotocin diabetic rats. J Biol Chem 251: 6053-6061

22. Buchanan KD, Mawhinney WAA (1973) Insulin control of glucagon release from insulin deficient rat islets. Diabetes 22: 801-803

23. Pagliara AS, Stillings SN, Haymond MW, Hover BA, Matschinsky FM (1975) Insulin and glucose as modulators of the amino acid-induced glucagon release in the isolated pancreas of alloxan and streptozotocin diabetic rats. J Clin Invest 55: 244-255

24. Weir GC, Knowlton SD, Atkins RF, McKennan KX, Martin DB (1976) Glucagon secretion from the perfused pancreas of streptozotocin-treated rats. Diabetes 25: 275-282

25. Schusdziarra V, Rouiller D, Harris V, Conlon JM, Unger RH (1978) The response of plasma somatostatin-like immunoreactivity in normal and alloxan diabetic dogs. Endocrinology 103: 2264-2273

26. Hermansen K, Ørskov H, Christensen SE (1979) Streptozotocin diabetes: A glucoreceptor dysfunction affecting D cells as well as $B$ and A cells. Diabetologia 17:385-389

27. Trimble ER, Gerber PPG, Renold AE (1981) Abnormalities of pancreatic somatostatin secretion corrected by in vivo insulin treatment of streptozotocin-diabetic rats. Diabetes $30: 865-867$

Received: 14 December 1981

and in revised form: 5 July 1982

Dr. V. Grill

Department of Endocrinology

Karolinska Hospital

S-104 01 Stockholm

Sweden 